\title{
Reported insulin pump temperature fluctuations lack clinical relevance
}

\author{
This article was published in the following Dove Press journal: \\ Medical Devices: Evidence and Research \\ 20 February 2017 \\ Number of times this article has been viewed
}

\section{Betsy B Dokken \\ Michael Rosinko \\ Tandem Diabetes Care, Inc., San Diego, CA, USA}

Correspondence: Betsy B Dokken

Tandem Diabetes Care, Inc.,

I 1045 Roselle Street, San Diego,

CA 92121, USA

Email bdokken@tandemdiabetes.com

\section{Dear editor}

In their recent paper, Vereshchetin et $\mathrm{al}^{1}$ suggested that the heat generated by the Tandem Diabetes Care, Inc. (San Diego, CA, USA) t:slim ${ }^{\circledR}$ Insulin Pump during battery charging is high enough to degrade insulin. There are several reasons that the arguments made in this paper are not relevant to patient use of the $t$ :slim Insulin Pump.

First, the temperature probe used by the investigators was attached to the rear of the $\mathrm{t}$ :slim Insulin Pump., on the outside of the cartridge. Insulin (water in this experiment) inside the cartridge is surrounded by a plastic sheath and covered by polycarbonate, providing 2 layers of material between the fluid and the temperature probe. Based on data from the study in question, an estimate of the temperature of fluid within the cartridge is pure speculation.

Second, the investigators charged the t:slim insulin pumps in a sealed chamber heated to $35^{\circ} \mathrm{C}\left(95^{\circ} \mathrm{F}\right)$ for a period of 180 minutes ( 3 hours). The extreme conditions created in the investigators' laboratory are not applicable to user experiences. It is highly unlikely that users will charge their t:slim Insulin Pumps in an unventilated environment in extreme heat for an extended time. In contrast to the authors' statement that charging the $t$ :slim Insulin Pump for 3 hours is "not an unlikely scenario", our findings suggest otherwise. Analysis of data from patient uploads into Tandem's t:connect ${ }^{\circledR}$ Diabetes Management Application software (Tandem Diabetes Care, Inc., data on file; 2016) found that the average time per charging session for the t:slim Insulin Pump is 30 minutes. The authors' own data demonstrate that charging the t:slim Insulin Pump under ambient conditions, even for an excessive period of time, did not result in a significant temperature increase.

In addition, labeling of insulin lispro, insulin aspart, and the Tandem Diabetes Care, Inc. t:slim Insulin Pump, t:flex ${ }^{\circledR}$ Insulin Pump, t:slim G4TM Insulin Pump, and $\mathrm{t}$ :slim X2 ${ }^{\mathrm{TM}}$ Insulin Pump (and all other brands of insulin pumps) instructs patients to avoid extreme temperatures. A user of any insulin pump who finds themselves in extreme conditions similar to the heated test in this study should be taking precautions to protect their insulin, as indicated in their pump and insulin labeling.

In summary, the implication that the t:slim Insulin Pump, when used as indicated, operates at a temperature inconsistent with the stability of insulin is not supported by the data presented. ${ }^{1}$ 


\section{Disclosure}

The authors report no conflicts of interest in this communication.

\section{Reference}

1. Vereshchetin P, McCann TW, Ojha N, Venugopalan R, Levy BL. Comparison of rechargeable versus battery-operated insulin pumps: temperature fluctuations. Med Devices (Auckl). 2016;9:371-376. 


\section{Authors' reply}

Paul Vereshchetin

Thomas W McCann Jr

Navdeep Ojha

Ramakrishna Venugopalan

Brian L Levy

Johnson \& Johnson Diabetes Care Companies, Chesterbrook, PA, USA

Correspondence: Paul Vereshchetin

Johnson \& Johnson Diabetes Care Companies, 965 Chesterbrook

Boulevard, Chesterbrook, PA 19087, USA

Tel + I 4843286229

Email pvereshc@its.jnj.com

\section{Dear editor}

The authors appreciate the response from Tandem Diabetes Care Inc., specifically Dr. Dokken and Mr. Rosinko, to the paper titled: Comparison of rechargeable versus batteryoperated insulin pumps: temperature fluctuations. ${ }^{1}$

The purpose of this paper was to investigate what effect(s), if any, certain technologies common to portable consumer devices might have when applied to the medical device space. In particular, recent recalls of portable devices due to rechargeable battery issues including significant overheating leading to fire, e.g. in Samsung Galaxy Note $7,{ }^{2}$ suggest that it is necessary to further assess the rechargeable battery technology and its integration into medical devices such as insulin pumps to evaluate potential risks to patient safety.

Apropos of the first point in the response letter, the authors' original hypothesis was that the temperature inside the plastic sheath would be higher than the external surface temperature of the cartridge. Therefore, the publication included external measurements. However, we did conduct an invasive study measuring the temperature inside the cartridge by making a small incision in the cartridge with an NSK ultrasonic cutter (Nakanishi Corporation, Tokyo, Japan) to insert the thermocouple probe (Omega Engineering Inc., Stamford, CT, USA). The invasive study showed, in agreement with the hypothesis, that the temperature inside the cartridge is even higher than on its surface. In particular, at its largest, the difference between the temperature inside the cartridge of a battery-operated pump and the temperature inside the cartridge of a pump using rechargeable battery constituted $9.5^{\circ} \mathrm{C}\left(17.1^{\circ} \mathrm{F}\right)$ compared to the largest difference of $6.4^{\circ} \mathrm{C}$ $\left(11.4^{\circ} \mathrm{F}\right)$ cited in the published study referenced earlier.

With regard to the opinion that the experiment temperatures are extreme, the investigators do not deem them such - in 2016, in Phoenix (AZ) alone, there were 51 days with average temperatures at or above $35^{\circ} \mathrm{C}\left(95^{\circ} \mathrm{F}\right)$ and 143 days with maximum temperatures at or above $35^{\circ} \mathrm{C}$ $\left(95^{\circ} \mathrm{F}\right) .^{3}$ Rechargeable pumps can be charged through the USB port with a portable charging device, a power bank, which makes the outdoors charging scenario a possibility. Our published study demonstrates that within $\sim 10$ minutes of charging in the $35^{\circ} \mathrm{C}\left(95^{\circ} \mathrm{F}\right)$ ambient temperature, the pump surface temperature crosses the insulin degradation threshold. Given the invasive experiment mentioned earlier, the temperature inside the cartridge can be assumed to be crossing the threshold even sooner. Therefore, not only the average time of 30 minutes, but even the recommended time of 10-15 minutes ${ }^{4}$ is enough to render the insulin in the pump compromised as per NovoLog ${ }^{5}$ and Humalog ${ }^{6}$ labeling information: "insulin in the pump reservoir should be discarded after at least every 6 days of use or after exposure to temperatures that exceed $37^{\circ} \mathrm{C}\left(98.6^{\circ} \mathrm{F}\right)$ ".

Based on the published study data, the invasive experiment data included herein, and the laid out arguments, the researchers stand by the conclusion that lithium-ion rechargeable battery pumps show substantial temperature increases during charging relative to battery-operated pumps and that under certain possible temperature and charging use cases, such increases can have negative effect on the insulin being used in the pump potentially leading to compromised therapy.

\section{Disclosure}

The study was sponsored by Animas Corporation. The authors report no conflicts of interest in this communication.

\section{References}

1. Vereshchetin P, McCann TW, Ojha N, Venugopalan R, Levy BL. Comparison of rechargeable versus battery-operated insulin pumps: temperature fluctuations. Med Devices (Auckl). 2016;9:371-376.

2. Rowe D [webpage on the Internet]. Samsung Could Be About to Release the Results From Its Galaxy Note 7 Probe. Fortune. 2016. Available from: http://fortune.com/2016/11/30/samsung-probe-galaxy-note-7/. Accessed December 1, 2016.

3. weather.gov [homepage on the Internet]. National Weather Service of the National Oceanic and Atmospheric Administration of the US Department of Commerce. Available from: http://w2.weather.gov/. Accessed November 25, 2016.

4. t:slim G4 ${ }^{\mathrm{TM}}$ [user guide]. Available from: https://www.tandemdiabetes. com/docs/default-source/product-documents/t-slim-g4-insulin-pump/ tslim-g4-insulin-pump-user-guide-b005630_c.pdf?sfvrsn=4. Accessed September 20, 2016.

5. NovoLog (insulin aspart [rDNA origin] injection) [prescribing information]. Available from: http://www.novo-pi.com/novolog.pdf. Accessed September 20, 2016.

6. Humalog (insulin lispro injection) [prescribing information]. Available from http://pi.lilly.com/us/humalog-pen-pi.pdf. Accessed September 20, 2016. 
Dove Medical Press encourages responsible, free and frank academic debate. The content of the Medical Devices: Evidence and Research 'letters to the editor' section does not necessarily represent the views of Dove Medical Press, its officers, agents, employees, related entities or the Medical Devices: Evidence and Research editors. While all reasonable steps have been taken to confirm the content of each letter, Dove Medical Press accepts no liability in respect of the content of any letter, nor is it responsible for the content and accuracy of any letter to the editor.

Medical Devices: Evidence and Research

Dovepress

\section{Publish your work in this journal}

Medical Devices: Evidence and Research is an international, peerreviewed, open access journal that focuses on the evidence, technology, research, and expert opinion supporting the use and application of medical devices in the diagnosis, monitoring, treatment and management of clinical conditions and physiological processes. The identification of novel
Submit your manuscript here: https://www.dovepress.com/medical-devices-evidence-and-research-journal devices and optimal use of existing devices which will lead to improved clinical outcomes and more effective patient management and safety is a key feature. The manuscript management system is completely online and includes a quick and fair peer-review system. Visit http://www. dovepress.com/testimonials.php to read real quotes from authors. 